\title{
Responsible Management-as-Practice: Mobilizing a Posthumanist Approach
}

\author{
Silvia Gherardi ${ }^{1}$. Oliver Laasch ${ }^{2} \mathbb{D}$
}

Received: 7 May 2020 / Accepted: 6 September 2021 / Published online: 22 September 2021

(c) The Author(s) 2021

\begin{abstract}
The emerging field of responsible management (RM) studies the integration of sustainability, responsibility, and ethics in managerial practices. Therefore, turning to practice theories for the study of RM appears to hold great promise of conceptual and methodological contribution. We propose a posthumanist practice approach for studying RM-as-practice. Managerial practices are conceived as the agencement of heterogeneous elements (humans, nonhumans, more-than-humans, materials, and discourses) that achieve agency in their being interconnected. Thus, RM is understood as processual, relational, emergent, and sociomaterial. We contribute a framework for the empirical study of RM-as-practice on the basis of three sensitizing concepts: situatedness, sociomateriality, and textures. We further discuss the implications of understanding responsibility as response-ability, an engaged practice for relating to the other and the RM researcher's role as internal to the practice agencement under study, thus, opening the debate on our own response-ability.
\end{abstract}

Keywords Responsible management $\cdot$ Responsible management-as-practice $\cdot$ Posthumanism $\cdot$ Agencement $\cdot$ Situatedness . Sociomateriality $\cdot$ Texture of practices

\section{Introduction}

This article is positioned within the responsible management (RM) literature, which we address from the point of view of the 'turn to practice' (Eikeland \& Nicolini, 2011; Gherardi, 2000; Miettinen et al., 2009). Its aim is to contribute to the foundation of an approach to RM-as-practice, grounded in a posthumanist practice theory.

Practice theories have greatly impacted several major streams of management and organization studies. In the last twenty years, we have witnessed the birth of strategy-aspractice (Vaara \& Whittington, 2012); leadership-as-practice (Raelin, 2020); entrepreneurship-as-practice (Thompson \& Byrne, 2020); marketing-as-practice (Hackley et al., 2008), and also ethics-as-practice (Clegg et al., 2007a). However,

Oliver Laasch

Oliver.laasch@manchester.ac.uk

Silvia Gherardi

silvia.gherardi@unitn.it

1 University of Trento, Via Verdi 26, 38122 Trento, Italy

2 University of Manchester, Booth Street West, Manchester M15 6PB, UK the potentialities of addressing RM-as-practice are still widely open and worthy of a more in depth exploration, since a theoretically grounded methodology for conducting practice-based studies may enrich the ever-evolving academic field of responsible management. Therefore, in this article, we develop a research agenda by interweaving the logic of practice with RM, starting with a brief introduction of our two domains.

Practice theories may be defined as a broad family of well-established theoretical approaches for understanding and explaining social and organizational phenomena in new ways (Nicolini et al., 2003; Reckwitz, 2002; Rouse, 2001; Schatzki, 2005; Shove et al., 2012). We are going to examine the internal articulations of practice theories in a dedicated section. However, we anticipate that the broad family of practice theories presents the following communalities: (a) practices constitute the horizon within which all discursive and material actions are made possible and acquire meaning; (b) practices are inherently contingent, materially mediated, and cannot be understood without reference to a specific place, time, and concrete historical context; (c) practices are social accomplishments, even when they are attributed to individuals; (d) while practices depend on reflexive human carriers to be accomplished, 
and perpetuated, human agent capability always results from taking part in one or more sociomaterial practices; and (e) practices are mutually connected and constitute a nexus, texture, field, or network (Nicolini, 2012: 214).

Under the label of RM, the three domains of ethics, responsibility, and sustainability are connected (Forray \& Leigh, 2012; Laasch et al., 2020c; Rasche \& Gilbert, 2015). RM recently has been defined as the "integration of sustainability, responsibility, and ethics into [...] managerial practice(s)" (Laasch, 2018: 9). To establish a basic shared understanding of RM across the three domains, we briefly outline each of them to highlight the terrain we build on.

The business and management ethics domain is concerned with questions of morally right or wrong decisions and behaviors in a business and management context (Crane $\&$ Matten, 2004). The study of ethical management can be subdivided into the three fields of normative ethics concerned with what the 'right' behavior is; descriptive ethics concerned with explaining why people engage in right or wrong behaviors; and ethics management concerned with the application of tools to facilitate right behavior (Laasch \& Conaway, 2015). Ethics management tools that materialize ethics are, for instance, codes of ethics or ethical oaths (Carollo et al., 2020; De Bruin, 2016). A related "crucial practice for responsible management" is whistleblowing, as a way to report ethical misconduct (Carollo et al., 2020: 594). Human beings, their central role as actors, and the emotional impacts on them by whistleblowing are at the forefront.

The sustainability domain can be traced back to the notion of sustainable development (Brundtland, 1987). It is concerned with complex systems dynamics between social, environmental, and economic dimensions (Barbier, 1987), which in the management context frequently is referred to as the triple bottom line (Dyllick \& Hockerts, 2002; Elkington, 1998). Another core concern of sustainability, emergent from the aspiration to sustain intergenerational equity (Padilla, 2002; Pearce, 1988), is time (Bansal \& DesJardine, 2014). In the context of management, sustainability practices are grounded in both corporate sustainability management and environmental management (Schaltegger et al., 2003). Sustainability management tools that materialize sustainability in RM include, for instance, sustainability score cards and life-cycle impact assessments (Finnveden et al., 2009; Hansen \& Schaltegger, 2014). As an example, Kennedy and Bocken (2020: 640) study "the essential practice" of RM that is business model innovation for sustainability. This practice centrally relies on design tools like the "triple-layered business model canvas" (Joyce \& Paquin, 2016: 1474). It emphasizes the role of a human responsible manager as the agent of sustainability business model innovation, as a practice "for the responsible manager" (Kennedy \& Bocken, 2020: 640).
The responsibility domain is centered on the realization of responsibilities between managers and a variety of stakeholders (Carroll, 1991; Fassin, 2009; Freeman, 1983). While most strongly related to the corporate social responsibility (CSR) discussion, the field often framed as business and society or as social issues in management, also includes corporate citizenship, responsible leadership, and social entrepreneurship (Schwartz \& Carroll, 2008; Waddock, 2004; Wood \& Logsdon, 2019). All emphasize the social dimension of responsibility (Aguilera et al., 2007; Dahlsrud, 2008). Tools that materialize managerial responsibility in practices are, for instance, stakeholder mapping, stakeholder prioritization, and total responsibility management (Mitchell et al., 1997; Van Marrewijk et al., 2004; Waddock \& Bodwell, 2004). The practices of socially responsible human resources management (SHRM) (Shen \& Benson, 2016) are an excellent example for social responsibility centered RM. The emphasis is on human beings, as it explores how HR managers' practice of SHRM affect the employee stakeholder's work behavior and how this in turn affects the assumption of their responsibility for other human stakeholders (Shen \& Benson, 2016: 1723).

RM research is not only interested in the individual domains of ethics, responsibility, and sustainability, but especially in the dynamics between them. For instance, Laasch (2021) discusses the practice of factory production interrelating its ethical implications related to worker (mis) treatment, with societal responsibility implications such as the impacts of shift work on families, and on environmentally unsustainable consumption patterns. Yet again, the humans are put front and center in this account.

While practice as a unit of analysis tends to focus the attention on activities, knowledges, discourses, and materialities that are brought together in practicing, RM research instead has been centered on the human, the responsible manager (Laasch, 2018; Prahalad, 2010; Schneider et al., 2010). Accordingly, RM frequently relates to specialized (human) job profiles, roles, and identities like those of ethics and compliance managers (Adobor, 2006), CSR managers (Wesselink \& Osagie, 2020), or sustainability managers (Carollo \& Guerci, 2017). The RM field also aims to understand and enable the RM by people more broadly, including "mainstream managers" (Laasch \& Conaway, 2015: 36), and "all employees of a company" (Verkerk et al., 2001: 354). It becomes apparent that the RM discussion has foregrounded the central 'human motor' or 'human agent.' Our posthumanist approach will background this human emphasis, in order to arrive at new and more diverse ways of studying RM.

Although RM has frequently used the term practice, with very few exceptions (Laasch et al., 2020a; Price et al., 2020), the RM literature has not tapped into the powerful research apparatus of practice theories. By developing a posthumanist 
practice approach to RM, we offer an apparatus for the study of RM practices that backgrounds the (human) responsible manager. Our aim is to de-center the human being as the main source of meaning and action and focus rather on how ethics, responsibility, and sustainability are entangled in the materiality and discursivity of situated practices. When we take practice as the unit of analysis, we do not deny a place to the humans, but they are positioned along with nonhumans (tools, technologies, other materialities), more-thanhumans (other living beings), discourses, knowledges, and any other specific element that may enter into a situated practice. Thus, if we understand responsible management as practice, RM may be further re-defined as emergent from the interplay of ongoing ethical, responsible, and sustainable practices.

This article is organized in the following way. First, we discuss the difference between humanist and posthumanist practice theory and our reasons for preferring the latter. In a second moment, we contribute a theoretical/methodological framework for approaching RM-as-practice, guided by some select sensitizing concepts (situatedness, sociomateriality, and texture). In the concluding discussion, we make explicit the implications of our posthumanist framework, by framing the field of RM-as-practice as processual, relational, emergent, and sociomaterial. We will also discuss the RM researcher's response-ability, which emerges from our being inside the practices we study.

\section{From Humanist to Posthumanist Practice Theories}

In the early 2000s, a conversation started around the "practice turn' (Schatzki et al., 2001) and practice theories began to inform management and organization studies (Gherardi, 2000; Orlikowski, 2000). After the so-called second wave of practice theorists (Bourdieu, 1990; Foucault, 1970; Garfinkel, 1967; Giddens, 1984), a new generation of scholars argued either for a re-turn to practice theories (Nicolini, 2012; Sandberg \& Tsoukas, 2015; Schatzki, 2019; Shove et al., 2012) or for a turn within practice theories (Gherardi, 2021). However, the umbrella term of practice-based studies accommodates both differences and similarities (Gherardi, 2019a; Hui et al., 2016). Nonetheless, a relevant line of differentiation can be drawn between humanist and posthumanist practice theories.

\section{Humanist Practice Theories and Ethics-as-Practice}

Humanist approaches start from human beings as the main source of agency and methodologically study 'humans and their practices' positioning the material world in relation to, but outside of practice. Practice is mainly seen as human activity (Schatzki, 2005). In fact, the widespread definition of practice as nexus of doings and sayings sustained by a shared understanding, induces an unintentional focus on the subject of those activities as a human being who possesses capacity for intentional action and ability to communicate. Another unintentional emphasis on the human subject stems from a conception of practice as simply 'what people do,' often in contrast with theory. Thus, practice has become a slippery term that has the propensity to slide unnoticed between empirical and analytical registers (Gad \& Jensen, 2014). On one side, there is the tendency - criticized by Turner (1994)- to ascribe to practice the status of a kind of object; a social substance with un-analyzed, but implied causal powers. On the other side, there is the tendency of turning practice into a magical charm, forgetting that practice is never simply 'found' but is always fabricated by the researchers' activities that draw boundaries around 'a' practice.

To study a practice as an empirical object, researchers draw boundaries around a set of activities that are socially recognized as belonging to a certain practice. For example, the identification of the categories that enter into the construction of the indicators for a CSR report, may be considered a practice. However, also the whole CSR reporting and communication to stakeholders may be considered a practice. Thus, the boundaries around ' $a$ ' practice are identified by researchers according to the needs of their study. At the same time, practice is a philosophical concept that articulates the set of characteristics that enter into the construction of a theoretical and analytical apparatus for the empirical study of practices. In other words, a humanist practice theory is not 'truer' than a posthumanist one. Rather each allows for a different conceptualization of the research object, the methodologies for studying it, and their capacity to produce different knowledge effects and discourses.

Before introducing a posthumanist practice theory, we acknowledge that our endeavor does not start from scratch, since practice-based studies of management and ethics-aspractice have paved the way for studies of RM-as-practice.

Despite the attention to the discourse on managerial work, the categorization of what constitutes managerial work has always been a controversial topic. Practice-based studies with their focus on the everydayness and creativity of managerial work, are positioned "as promising means of addressing some of the short-comings of existing approaches, aimed at facilitating the making of novel connections" (Korica et al., 2017: 152). Managerial work is framed by them as a practiced craft whose knowledge is developed and kept within situated practices of managing. Often, a practicebased understanding of management is fostered with the expression 'managing' or managing responsibly (Price et al., 2020). 
An approach to ethics-as-practice is becoming well established (Carter et al., 2007; Clegg et al., 2007a, 2007b; Ibarra-Colado et al., 2006; Loacker \& Muhr, 2009; PainterMorland, 2008; Pérezts et al., 2011). The basic premises of ethics-as-practice are as follows: (i) ethics is a practice of choice and evaluation; (ii) in practice, people encounter a plurality of ethical models; and (iii) novel situations can never be entirely predicted by a model. Ethics is, thus, defined as "the social organizing of morality; the process by which accepted (and contested) models are fixed and refixed, by which morality becomes ingrained in various customary ways of doing things" (Clegg et al., 2007a: 111). In this definition, we may note that the collective organizational foundation of ethicality, its open-endedness, and a definition of practice as a habitual way of doing. Therefore, management's task in relation to ethics is one of "enhancing and maintaining structures that understand undecidability as opportunities and responsibilities [...] and that actively foster a collective and democratic decision-making ethos" (Clegg et al., 2007b: 395).

Ethics-as-practice constitutes a relevant theoretical move for grounding the empirical study of ethics in situated managerial practices. Also, other studies assume an approach that contributes to counter imposed ethical universalism, stressing, for example, the local and continuous emergence of morality through value work (Garud et al., 2018; Gehman et al., 2013). Nevertheless, we notice two weak points in this research agenda. One is the separation of ethics from politics. The other is the centrality still attributed to humans as the exclusive locus of morality and decision making. Therefore, we wish to stress the need to link ethics and politics, as many authors do, under the label of critical business ethics (McMurray et al., 2011; Rhodes \& Pullen, 2018; Wray-Bliss, 2009).

When faced with multiple demands from multiple others, people at work will always violate ethics in the way they constitute their own subjectivity, since taking political action means that the ethical demands of every single other person cannot be accounted for. Therefore, "ethical subjectivity in organizations is not a matter of firming up a singularly righteous self, but is a divided self, willing to address the fragile and undecidable character of its own constitution in practice" (McMurray et al., 2011: 543). This theoretical point about subjectivity constitutes the linking pin for discussing the difference between human-centered practice theories and an alternative approach. In fact, as long as we operate with a conception of humans as the central agent and the only ones who possess agency, we assume that an ethical subjectivity precedes the practice in which it is enacted.

\section{Posthumanist Practice Theory}

A posthumanist practice theory (Gherardi, 2019a) has been elaborated on the basis of contemporary philosophical conversations labelled as posthumanism and new materialism. Posthumanism is often used as an umbrella term, subsuming new materialism and affects studies (Fox \& Alldred, 2016). It is used in many fields to describe mainly two themes that affect both the definition of the subject of knowledge and the modes of knowledge production: posthumanism on the one hand and post-anthropocentrism on the other. The former criticizes the idea of 'Man' as the allegedly universal standard for the human, whereas the latter objects to species hierarchy and human exceptionalism (Braidotti, 2013). The humanist subject has been considered problematic for many reasons: its exceptionalism, eurocentrism and masculinism, along with its anthropocentrism (Braidotti, 2013). Nevertheless, decentering the human as an individual, does not imply a rejection of the human/humanity, but rather a rejection of the centrality of humans as the site of intentional action. Human beings never act alone and are always entangled with/in their environments. Thus, it acknowledges a postanthropocentric commitment to thinking 'beyond the human,' in terms of dynamic relations among humans, animals, machine, discourses, things, environments and, thus, expressing a firm stand against liberal humanist individualism.

A posthumanist practice theory, in denying the centrality of humans, defines practice as an agencement ${ }^{1}$ of elements (humans, nonhumans, more-than-humans, discourses, bodies, rules, knowledges) that achieve agency in their being intra-acting. Intra-action refers to the mutual constitution of entangled agencies. In contrast to 'interaction,' which assumes that there are separate individual agencies that precede their interaction, the notion of intra-action recognizes that distinct elements emerge through their intra-action (Barad, 2007: 33). Therefore, what we name 'a practice' emerges from the diverse and diffuse field of entangled elements that achieve agency performatively, in their reciprocal affecting and being affected. A practice, as a socially sustained mode of knowing and acting, emerges from its practicing, from the capacities of its elements to affect and to be affected which produce novelty and heterogeneity. Here, we see the main difference to a humanist practice theory

\footnotetext{
1 The reason for preferring to keep Deleuze and Guattari's (1987) French word, poorly translated in English with assemblage, is that the French term retain its root in agency and has a processual connotation - the idea of establishing or forming an assemblage - not a fixed state of assembled things. The difference that is thus introduced aim to shift the attention away from what is interconnected towards how the elements that are entangled achieve agency by being interconnected (Gherardi, 2016).
} 
that attribute agency to individual actors, separated from the materiality and discursivity of the world in which they act, whereas in a posthumanist conception agency emerges within the temporal and performative flow of practicing.

To give an example of the difference between humanist and posthumanist approaches in empirical research in $\mathrm{RM}$, we can take gender and gendering practices in CSR as a well-developed topic of research that may be re-framed. Corporate social responsibility (CSR) practices begun to engage with gender issues in a variety of ways, both through initiatives relating to women in the workplace, community, and supply chains as well as through broader CSR programs (Women's Empowerment Principles). Guidelines and benchmarks on gender equality have materialized the tools for mitigating inequality. Women empowerment initiatives are often incorporated as part of mainstream CSR reports and ethical trade initiatives. Stakeholder consultations on gender issues are becoming widespread and local CSR program developments are diffused. We can say that managerial practices in relation to gender issues have been well developed for what concerns the instruments for accounting, reporting, and communicating with stakeholders, thus, accumulating legitimation resources for the firm. What has not achieved enough visibility, however, is the theoretical reflection for such initiatives in relation to feminist theorization on gender and gendering practices (Grosser \& Moon, 2019); the meaning of empowerment in developing countries (Karam \& Jamali, 2013); the unexpected outcomes of empowerment programs enacted by women managers and farmers (McCarthy, 2017); and the gendered global division of labor between Global North/South that reproduces gendered neocolonialist discourses and perpetuate exploitative material dependences through CSR activities (OzkazancPan, 2019). If we put together the results of those studies and read them diffractively through one another, we can reframe CSR practices as the agencement of humans (managers, workers, stakeholders, and many others), nonhumans (accounting systems, technologies, categorization processes, programs), discourses (empowerment, CSR, equality, vulnerability), and knowledges (Western, postcolonials). From the local workplace initiatives, all these together connect to the community and the world, thus, globalizing both CSR management instruments and the meaning of empowerment and inequalities. We can empirically trace the flow of agency through the way that one element affects another and travels both as idea and as its materialization, in a social and material valorization process.

This principle of 'agentivity' means that we do not study managers as individuals or collectives, managerial work and activities, management discourse in isolation, nor managerial education or learning as separate activities rather we study the social effects of their interconnections. The divide between 'us' and the world, or the organization and the environment, is blurred since all are part of the world and part of the apparatus with which we come to know the world.

In encouraging us to stop viewing matter as a passive and immutable substance, a posthumanist practice theory follows the so-called 'turn to matter.' Specifically Barad's (2007) work theorizes the intertwined and co-constitutive relationship between discursive practices and material phenomena. Phenomena are produced through specific apparatuses, which are not bounded objects or structures. Instead, they are open-ended practices of mattering through which intelligibility and materiality are constituted, along with an excluded realm of what does not matter. Thus, researchers are responsible for their own knowing practices since they are internal to the practice agencement they study.

Our being part of the world expresses not only a critique of anthropocentrism but also implies a research agenda in which a posthumanist practice theory may become a generative tool in the historical moment named 'Anthropocene.' The idea of a posthuman societal condition reflects a situation in which matter is vital and human and nonhuman are more and more folded into one another: agencements of digital cultures, emergent bio-technologies, algorithmic automation, and various cyborg formations are deeply enmeshed.

An appropriate question for positioning sustainability within a posthumanist practice theory is to ask with Ulmer (2017: 6), "what the Anthropocene might do in research." She answers that it may do several things "situate research within a particular time period; support inquiries that include aspects of in/non/human life; and highlight the purpose and significance thereof. Anthropocentric thinking invites scholars to refine their political commitments both in and to research" (Ulmer, 2017: 6). In her response, we acknowledge how in doing research, sustainability, responsibility, and ethics are not separable. This insight is at the core of a posthumanist practice theory (Gherardi, 2019a) that acknowledge the performativity of our social practices. Therefore, instead of asking what individuals 'do' within a practice, we shall ask what practices do, and with which effects in terms of ethics, responsibility, and sustainability. For us, as researchers, it is also a matter of ethical responseability to be aware of the relationality of knowing and being with doing. Both Haraway (2016) and Barad (2007) use the term 'response-ability' to emphasize the performative feature of responsibility that entails "cultivating collective knowing and doing" (Haraway, 2016: 34), a relational attitude towards all beings. In this regard, Haraway's concept of response-ability includes an ability to sense, 'share,' and respond to others.

The plea for a concept of ethico-onto-epistemology (Barad, 2007), informing posthumanist practice theory, opens a different ground for ethics. It is an embodied ethics that lies in our corporeal sensibility to proximate others (Diprose, 2002; Perezts et al., 2015; Pullen \& Rhodes, 
2013). Within the philosophical movement of posthumanism, feminist new materialism, and ethics of care, a posthumanist practice theory may contribute to developing the field of RM-as-practice redefining responsibility as response-ability, the capacity/ability to respond to the other.

\section{A Theoretical/Methodological Framework for the Empirical Study of RM-as-Practice}

In this section, we develop a theoretical/methodological framework for the empirical study of RM as a phenomenon emergent in and through practice. In a sense, we have already illustrated our theoretical framework exposing the basic assumptions of a posthumanist understanding of practice. Our next task is to translate it into a coherent and accessible research framework. However, to stay loyal to the posthumanist philosophy, we are expressly resist to dividing theory/practice, researchers/researched, and the temptation to produce knowledge standing outside of the world [what Haraway (1988) called knowledge from nowhere, alias the God trick]. This choice is grounded in an ethico-onto-epistemological assumption that does not begin with the cogito of preexisting, formalized, systematized, instrumental methodologies commonly in use (Gherardi, 2019b).

In other words, we cannot study RM practices standing outside the research agencement in which researchers and managers, materialities, and discourses are entangled, are provisional and precariously kept together, since they are becoming with the research practice itself. As post-qualitative methodologies have pointed: "entanglement makes all the categories of humanist qualitative research problematic. For example, how do we determine the 'object of our knowledge' -the 'problem' we want to study in assemblage? Can we disconnect ourselves from the mangle somehow (Self) and then carefully disconnect some other small piece of the mangle (Other) long enough to study it?" (Lather \& St. Pierre, 2013: 630).

A possible solution is to bypass the theory/method divide and to think in terms of "concepts as method" (Taguchi \& St. Pierre, 2017: 643) or concepts instead of method (Colebrook, 2017) for not relying on conventional social science research methodologies. Inspired by Deleuze and Guattari's (1994: 21) work and its reading by Colebrook (2017), a concept is understood as 'an act of thought' and it creates orientations for thinking. It is in this respect that Colebrook (2017: 654) writes: "we might begin to think of concepts as methods, precisely because concepts are at once prehuman (emerging from the problems or plane of thinking in which we find ourselves), but they also reconfigure or reorient the plane precisely by being prompted by a problem. Concepts are methods precisely because they emerge from problems rather than questions." While questions are of such a nature that they already have a determined field of answers, problems, by contrast, require a reconfiguration of the lexicon within which questions are currently articulated.

Therefore, we propose a theoretical/methodological framework that may orient empirical research on RM practices suggesting three concepts 'to think-with': situatedness, sociomateriality, and texture (see Table 1).

\section{Situatedness}

Situatedness is the first concept that we offer to explore the empirical study of RM-as-practice. We stress again that managerial work is understood as a practiced craft, thus, connecting the situatedness of managerial knowing-inpractice (Gherardi, 2006) with the contingency of in situ practices and activities. In fact, situated knowledge (i.e., knowledge conceived as an activity, as knowing-in-practice) points to the radical historical contingency for all knowledge claims and knowing subjects. It originates from the following questions: What counts as (legitimate) knowledge, within an institutionalized body of knowledge as management for example? Whose knowledge counts as knowledge? How is practical knowledge actually made? Beyond such questions transpires the concern with power and with a form of knowing in an ethically accountable manner.

Having situatedness in mind we ask: How is responsible managing accomplished in situ, in a situated practice, which assembles humans, nonhumans, tools, technologies, rules, and discourses? Which activities are performed within the situated RM practice that we describe, and with which consequences in terms of sustainability, responsibility and ethics? How can the practice at hand be done differently? How can it be that a practice produces more or less responsible effects? While management studies usually pursue universal and decontextualized principles, responsible managing is focused on the here and now, on the temporality and spatiality of practice. It is conceived as a situated mode of ordering humans, nonhumans, tools, technologies, rules and discourses that produce (or not) responsible effects in terms of environmental impact, community engagement, mobility, responsible purchasing, and sustainable consumptions, to name just some main effects.

A first step towards the study of RM-as-practice can be found, for instance, in the insight by Pérezts et al. (2011) that $\mathrm{RM}$ is an enactment of ethics in practice. Within paradoxical injunctions in situated organizing, managers "reshape their practice as a situated construction through constant mediation between different 'masters' and bricolage (i.e., tinkering with concepts)" (Pérezts et al., 2011: 33). The implicit question behind this study is: How is a practice practiced? It is inextricably linked to the twin question of, what are the effects of a practice that is recursively practiced? For example, Hibbert and Cunliffe (2013: 177) answer that "an 


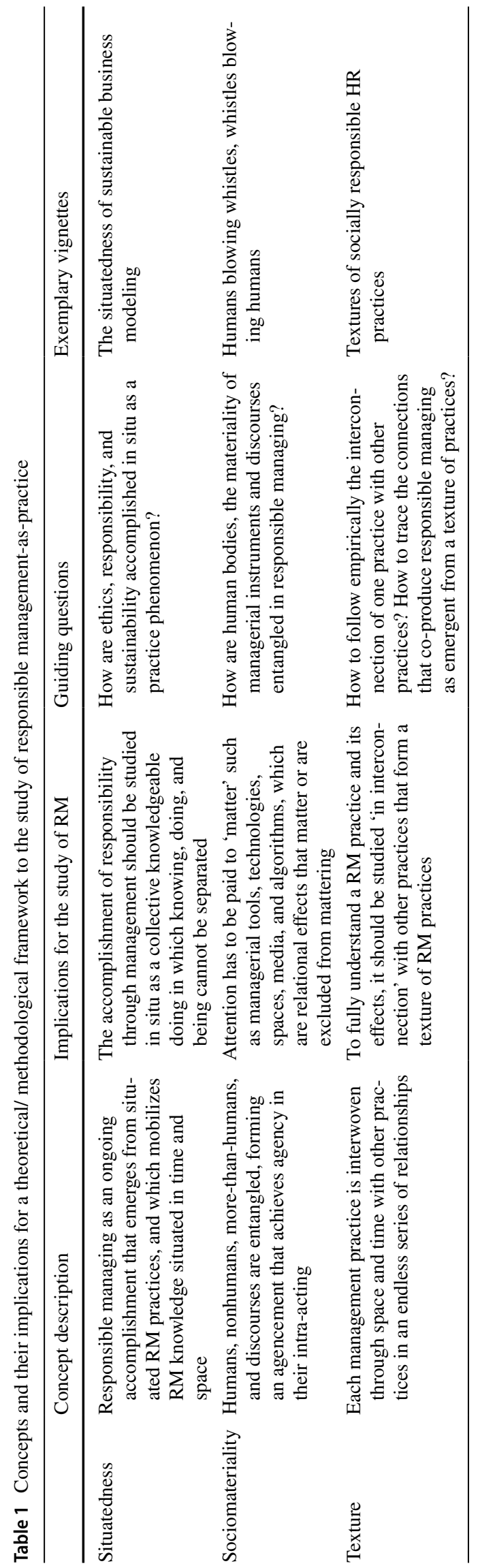

abstract knowledge of principles has to be supplemented by an engaged understanding of the responsibility of managers and leaders to actively challenge irresponsible practices."

For example, if we want to study a practice of business model innovation for sustainability - with situatedness in mind - we would frame it as business modeling for sustainability, a locally entangled, situated type of responsible managing that produces the transient effect that is a sustainable business model. As an example, let us imagine how we would study business modeling for sustainability 'in situ' at a fictional Danish disposable diapers producer. Here, management aims to change their business model to become a 're-usable diapers club' with a membership scheme. Through the lens of situatedness, we would observe how the new business model is collectively produced in situ, for instance, by environmental managers, parent-activists, and new suppliers. We would focus on their knowing-in-practice, on how they mobilize local, situated knowledge, such as the knowledge of unique sustainable production, consumption, and circular logistics practices and their socio-environmental impacts. This situated responsible managing would also engage with local discourses (e.g., the EU discourse about sustainability transitions and the city of Copenhagen's unique version of the Donut Economics Model). Their situated activities would produce and use unique devices, such as a visualization of the company's circular business model canvas tool. Such a study of the situated practicing of business modeling for sustainability emphasizes the situated emergence of sustainability as an effect from 'in situ' practicing. The situatedness concept allows us to arrive at findings that are distinct from the more common top down study of sustainable business model design. In such studies, global templates or patterns of sustainability business models are understood to either be 'predesigned' or existing on a higher level, to then be customized or adapted to fit local settings.

\section{Sociomateriality}

As discussed in our introduction of posthuman practice studies, the turn to matter attributes agency also to nonhumans, more-than-humans, and discourses. Moreover it implies that the social and the technical form an ecology of knowing, and that the introduction of a new artifact, technology or tool, produces a realignment of practices, which is both material and cultural (i.e., sociomaterial). The concept of sociomateriality enables us to ask questions such as: How is knowing materialized in managerial tools that are kept, innovated, and discarded? How is this knowing embedded in specific artifacts, devices in use in order to perform accountability? What are the effects on the adoption of certain devices of monitoring activities on organizing for responsibility? 
We may say that artifacts have policy since sustainability, responsibility, and ethics are embedded in the way humans, nonhumans, and discourses form an agencement that achieve agency from the entangled elements. This concept can also be exemplified by, Painter-Morland's (2011: 91) insight that "'responsible management' is an emergent part of an ongoing set of connections and responses to connections" in the managerial agencement. RM practices, therefore, are always a sociomaterial, human-nonhuman, and heterogeneous accomplishment (Laasch et al., 2020b).

To give an example of what we mean with sociomateriality, we point to the pervasiveness of algorithmic technologies. Elmholdt et al. (2020) studied what happens when a company launches a wellbeing initiative targeting their employees' sleep habits via digital self-tracking. The initiative was motivated by the belief that private and work lives have become inseparable, and well-rested employees are both healthier and perform better. Therefore, employees were invited 'to help themselves' by improving their sleep. With this story, we want to emphasize how the digital artifact embodies the ability to turn qualitative outputs into numerical ones. This in turn enables more extensive options for control that mobilize employees in different ways in respect to bureaucratic and technical modes of control. In fact, algorithmic control revolves less around the human manager and more around employee interaction with a nonhuman algorithm, effecting a "disintermediation of managers" (Kellogg et al., 2020: 387). The dark side of digitalization may be seen as a contemporary phenomenon, part of posthuman societal condition.

To give another example of the sociomaterial performativity of a practice, we can refer to whistleblowing by allowing our gaze to wander away from the human agent blowing the whistle. By doing so, we study the wider sociomaterial agencement of whistleblowing: entangled material communication technologies ('the whistle'), human whistleblowers, and the ones on whom the whistle is blown, organizational structures, values, and whistleblowing policies. The agencement also includes organizational and societal discourses about what constitutes unethical behavior worth blowing the whistle on. The human whistleblowers are not ignored, but rather take their place inside the agencement that constitutes the RM practice of whistleblowing. By doing so we are at the same time studying how the whistleblower blows the whistle and how 'the whistle is blowing the whistleblower.' They are inseparable in the sociomaterial agencement that enacts whistleblowing. In turn, the whistleblowing practice also 'produces' the actors in the agencement. The whistleblower only is one when enrolled in the whistleblowing agencement and a telephone line only becomes a whistleblowing hotline in the whistleblowing agencement. Therefore, we propose to study agencement not as a noun, but as a verb; not as a 'static' thing, but as an ongoing process in which humans, nonhumans, and discourses are generatively entangled and intra-acting through the RM practice of whistleblowing.

\section{Texture}

The interconnectedness of one practice with other practices can be empirically traced following their interweaving in a texture of practices. The term texture of practices (Gherardi, 2006) denotes connectedness in action; how each practice is interdependent and interwoven with other practices. This term brings out the ordering feature of texture, its endless series of relationships, which continually move into each other. ${ }^{2}$ It enables us to pose questions related to the connections of one practice to other practices and to trace the relationships that are formed between a practice 'here and now' and its connection and manifestation within other practices that may be far in time and in space.

When we follow this line of reasoning, we see how the distinction between micro and macro and between the internal and external of an organization is dissolved. The inherent complexity in studies of responsibility can be approached empirically in trailing the connections in action from one practice to interconnected practices, to the world in which we trace their effects. The study of a single RM practice offers a rich understanding of a way of doing $\mathrm{X}$ responsibly. The consideration of a texture of practices, conversely, allows to move along the connections of 'practicing $X$ ' with other interconnected more or less responsible management practices. It allows us to trail the connections, while they are weaving the texture of responsible managing as a set of interconnected practices that materialize the social understanding of 'responsibility' in a given society, in a given historical time, and with given material infrastructures (including the research's apparatus). The discussion of constellations of interconnected transdisciplinary practices of RM learning, spanning across managerial, research, and educational fields, is grounded in this insight (Laasch et al., 2020a).

How would we, for instance, study the practice of socially responsible human resources management (SRHRM) as a texture of practices? We would trail the connections to other practices of a situated SRHRM practice such as considering employees' social performance as part of promotion. By doing so, we would discover how it is interwoven with even further SRHRM practices such as hiring socially inclined employees and training employees for stakeholder

\footnotetext{
2 The interconnection of practices is a theme central in several practice theories for which other authors coined similar concepts: Pickering's (1993) mangle of practices, bundle or nexus of practices (Hui et al., 2016), by Shove et al. (2012) connective tissue. Texture in comparison with these other concepts stresses an ordering principle (weaving as connecting weft and warp) that is absent from the others (Gherardi, 2006).
} 
engagement. We are likely to also discover how these practices span beyond organizational boundaries and further interweave with practices of stakeholder and community involvement, which in turn are interwoven with varieties of stakeholders' and communities' practices. Similarly, SHRM practices like training employees in carbon literacy, are interwoven with employees' carbon-emitting practices in private and professional life (e.g., the commute to work). This tracing in turn highlights SHRM practices' interweaving with societal practices of environmental and planetary significance, from practices of transport to those of waste disposal.

By trailing the connections in this way, we are able to see how the expanding texture of SRHRM practices is continuously interwoven. We are also able to trail connections into past and future, for instance, to trace back the roots of an irresponsible HR practice. As an example, normalized excessive overtime could be traced back to 'predecessor practices' of purposive under-staffing in previous periods. Or in turn, it could be 'traced forward' even to potentially extreme practices such as employee suicide. ${ }^{3}$ Trailing SRHRM practices may reveal explanatory patterns in the interweaving of the texture, which may elucidate the nature of relations between practices in a texture. It may also enable us to appreciate ir/responsible effects emergent from that texture (e.g., suicides, community wellbeing, $\mathrm{CO} 2$ emissions) that are not well explained by studying a practice in isolation.

\section{Concluding Discussion: Framing RM-as-Practice and Researchers' Response-Ability}

In this concluding section, we want to frame the new stream of research, which we labeled RM-as-practice. We will do so by outlining the implications of the novel theoretical/ methodological posthumanist framework for the empirical analysis of RM practices that integrate ethics, responsibility, and sustainability. We will also discuss the implications of this frame for RM researchers' response-ability.

In particular, we brought forward the conception of managerial work as a practiced craft (Korica et al., 2017) whose knowledge is developed and kept within situated practices of managing. We position management within practicing and as a form of knowing-in-practice (an art or a craft rather than a scientific discipline). This positioning generates an epistemological shift from ontological issues (what a knowledge

\footnotetext{
${ }^{3}$ Given the extreme nature of this example, we feel obliged to reference our inspiration to use it which came from the enduring suicides that had emerged in particular in France Telecom in the mid 2000s and at Foxconn in the early 2000s.
}

object-such as RM- 'is') to onto-epistemological ones (how that object-managing responsibly-is done, and how it comes to be temporally accomplished within situated practices). Therefore, we have constructed RM as processual and have implied that a contingent and process-oriented approach is suited for studying it in cultural, geographical, and historical specific circumstances. We have substituted the object 'management' with the process 'managing.' This linguistic operation signals a change of perspective from self-standing entities to entities in their becomings. Thus, RM can be defined also as relational and not only processual. We propose therefore that in the study of a RM practice, we move from questions of what (for example which elements or activities, or tools, or actors) to questions of how those elements are entangled, i.e., from questions of being to questions of becoming.

Thus, responsible managing may be qualified as emergent in and through situated practices, rather than the application of a decontextualized 'best practice' that is exported to a local context. Most of the knowledge that in CSR (just to name one field of RM) has been codified, institutionalized and materialized in codes and guidelines (i.e., decontextualized) is expected to produce 'responsibility' as an effect when it is re-contextualized anew. When this expectation is not met, conventional research puts forward explanations in terms of unintended outcomes, mis-fit, sloppy management, or limits intrinsic to capitalist functioning of economy and of economic hierarchization of priorities. However, if researchers study management practices as situated, their expectations are that ethics, responsibility, and sustainability will be emergent effects that may or may not manifest themselves within the situated practice. The empirical attention is, thus, shifted from questions of why a certain effect happens or should happen to problems of which circumstances favor or hamper the way that the elements in the practice agencement intra-act.

Framing RM as emergent within a practice agencement implies a changed conception of agency since it is not assumed as a human attribute. Nor has it been extended to humans and matter as well, but it is emergent from the entanglement of heterogeneous elements (nonhumans, more-thanhumans and discourses) that achieve agency in their being intra-acting. To focus on the entanglement of humans and nonhumans is particularly relevant when we turn to inquire into technologies, artifacts, or tools through which managerial systems are constructed. All the instrumentation (and the very process of instrumenting) is embedded and embodied in materiality and 'possesses' agency and ethics. The body is the first materiality through which we do not relate to the world - as if it were external to 'us' - but 'we' are part of the world. RM is not only processual, relational, and emergent, but is also sociomaterial. 
The proposal is, therefore, to look at a situated RM practice as the agencement of heterogeneous elements and to position 'a' practice within a texture of interconnected practices. The flow of practicing connects practices in a web of mutual connections, more or less tight or loose. Tracing the connections between a practice and the other practices in which the former appears, becomes a methodology for moving along the scale of social phenomena without assuming a distinction between micro- and macro-phenomena (micro or macro CSR for example).

Thus, in doing empirical research on RM, we do not stop at the borders of 'an' organization, nor of a way of managing. Rather we look at how nature and culture are entangled. We pose concrete questions around the consequences of managerial practices to the world we inhabit and around how our worlding can be done differently. RM practices can be framed as processual, relational, emergent, sociomaterial, and contingently interconnected rather than essentialist or absolute. Exploring the relational character of events and their physical, biological, and expressive mingling becomes an important analytical means to study the continuities, fluxes and 'becomings' that produce the world around us.

The processuality, materiality, relationality, and situatedness of RM lead us to discuss not only onto-epistemological issues but also ethico-onto-epistemological ones, since they are key in the way RM-as-practice can be framed. We do it both in relation to ethics as response-ability and to ethics as researchers' responsibility in research practices. We have already stressed how an approach to ethics-as-practice has generated a shift from universal values to situated doings and to the social judgments sustaining practices. However, the turn to matter opens an alternative discourse about ethics focusing on care, corporeality, and response-ability. The feminist new materialist ethic of care is opposed to the ethic of justice, since the morality of care emphasizes the importance of response, and it rests on the understanding of relationships as a response to another on their terms. It changes the moral perspective from the question of "what is just?' to the question of 'how to respond?' Feminist studies and feminist science and technology studies have been highly influential in theorizing an ethic of care whose logic is antagonistic to the ethic that emphasizes universal standards and impartiality. For Diprose (2009), a feminist philosopher, the body and its interactions and dependence on other bodies is the origin of corporeal ethics, and Michael Henry's phenomenological philosophy is the inspiration for the embodied ethics of Perezts et al. (2015) that re-frames stakeholder theory (Painter et al., 2021). In these elaborations, the openness to others is pre-reflective and this generosity and hospitality to others is corporeal and precedes rationality and cognition. Pullen and Rhodes (2013: 792) wrote "ethics is something that we can do, but not something that ever gets finally done.” As Puig de la Bellacasa (2011: 90) stresses, "but 'to care' more strongly directs us to a notion of material doing. Understanding caring as something we do, extends a vision of care as an ethically and politically charged practice" (emphasis in original).

Within the framing of RM-as-practice, the concept of response-ability shifts the emphasis from an ethics of accountability to an ethics of engagement with humans, nonhumans, more-than-humans, and the world. Thus, it means reframing also responsibility and sustainability as material engagement with the world. When we contemplate an ethics of engagement, we have to re-consider the position of the researchers and their ethico-onto-epistemological practices in delineating the object of research and how it is constructed by the research apparatus. In other words, we cannot study RM-as-practice standing outside of it as if we were neutral and detached observers. Researchers are response-able in their being part of the research agencement. Putting ourselves as internal, we expose how our epistemic practices redefine the field of RM as the product of distributed, expansive processes, associations, and encounters in practices between multiple human, discursive, and material components and the vital forces that emerge from their encounters.

In doing research inspired by RM-as-practice, as researchers we have the opportunity to re-immerse ourselves in a materiality of work life that is plural and complex, uneven and contingent, relational, and emergent.

Acknowledgements We are grateful for the feedback received on previous versions of this paper at the 8th Nordic Conference on Adult Education and Learning, in 2019, and during the 2021 Spring Seminar Series of the New Organization and Management Practices Group at Mälardalen University.

\section{Declarations}

Conflict of interest Silvia Gherardi and Oliver Laasch declare that they have no conflict of interest.

Open Access This article is licensed under a Creative Commons Attribution 4.0 International License, which permits use, sharing, adaptation, distribution and reproduction in any medium or format, as long as you give appropriate credit to the original author(s) and the source, provide a link to the Creative Commons licence, and indicate if changes were made. The images or other third party material in this article are included in the article's Creative Commons licence, unless indicated otherwise in a credit line to the material. If material is not included in the article's Creative Commons licence and your intended use is not permitted by statutory regulation or exceeds the permitted use, you will need to obtain permission directly from the copyright holder. To view a copy of this licence, visit http://creativecommons.org/licenses/by/4.0/. 


\section{References}

Adobor, H. (2006). Exploring the role performance of corporate ethics officers. Journal of Business Ethics, 69(1), 57-75.

Aguilera, R. V., Rupp, D. E., Williams, C. E., \& Ganapathi, J. (2007). Putting the $\mathrm{S}$ back into corporate social responsibility: A multilevel theory of social change in organizations. Academy of Management Review, 32(3), 836-863.

Bansal, P., \& DesJardine, M. R. (2014). Business sustainability: It is about time. Strategic Organization, 12(1), 70-78.

Barad, K. (2007). Meeting the universe halfway: Quantum physics and the entanglement of matter and meaning. Duke University Press.

Barbier, E. (1987). The concept of sustainable economic development. Environmental Conservation, 14(2), 101-110.

Bourdieu, P. (1990). The logic of practice. Stanford University Press.

Braidotti, R. (2013). The posthuman. Wiley.

Brundtland, G. H. (1987). Presentation of the report of the World Comission on Environment and Development to UNEP's 14th governing council. Nairobi.

Carollo, L., \& Guerci, M. (2017). 'Activists in a suit': Paradoxes and metaphors in sustainability managers' identity work. Journal of Business Ethics, 148(2), 249-268.

Carollo, L., Pulcher, S., \& Guerci, M. (2020). Whistleblowing as a crucial practice for responsible management. In O. Laasch, R. Suddaby, R. E. Freeman, \& D. Jamali (Eds.), The research handbook of responsible management (pp. 594-605). Edward Elgar.

Carroll, A. B. (1991). The pyramid of corporate social responsibility: Toward the moral management of organizational stakeholders. Business Horizons, 34(4), 39-48.

Carter, C., Clegg, S., Kornberger, M., Laske, S., \& Messner, M. (Eds.). (2007). Business ethics as practice: Representation, reflexivity and performance. Edward Elgar.

Clegg, S., Kornberger, M., \& Rhodes, C. (2007a). Business ethics as practice. British Journal of Management, 18(2), 107-122.

Clegg, S., Kornberger, M., \& Rhodes, C. (2007b). Organizational ethics, decision making, undecidability. The Sociological Review, 55(2), 393-409.

Colebrook, C. (2017). What is this thing called education? Qualitative Inquiry, 23(9), 649-655.

Crane, A., \& Matten, D. (2004). Business ethics. Oxford University Press.

Dahlsrud, A. (2008). How corporate social responsibility is defined: An analysis of 37 definitions. Corporate Social Responsibility and Environmental Management, 15(1), 1-13.

De Bruin, B. (2016). Pledging integrity: Oaths as forms of business ethics management. Journal of Business Ethics, 136(1), 23-42.

Deleuze, G., \& Guattari, F. (1987). A thousand plateaus. The University of Minnesota Press.

Deleuze, G., \& Guattari, F. (1994). What is philosophy? Columbia University Press.

Diprose, R. (2002). Corporeal generosity: On giving with Nietzsche, Merleau-Ponty, and Levinas. State University of New York Press.

Diprose, R. (2009). Toward an ethico-politics of the posthuman: Foucault and Merleau-Ponty. Parrhesia, 8, 7-19.

Dyllick, T., \& Hockerts, K. (2002). Beyond the business case for corporate sustainability. Business Strategy and the Environment, 11(2), 130-141.

Eikeland, O., \& Nicolini, D. (2011). Turning practically: Broadening the horizon. Journal of Organizational Change Management, 24(2), 164-174.

Elkington, J. (1998). Cannibals with forks: The triple bottom line of 21 st century business. New Society Publishers.

Elmholdt, K. T., Elmholdt, C. W., \& Haahr, L. (2020). Counting sleep: Ambiguity, aspirational control and the politics of digital self-tracking at work. Organization. https://doi.org/10.1177/ 1350508420970475

Fassin, Y. (2009). The stakeholder model refined. Journal of Business Ethics, 84(1), 113-135.

Finnveden, G., Hauschild, M. Z., Ekvall, T., Guinée, J., Heijungs, R., Hellweg, S., Koehler, A., Pennington, D., \& Suh, S. (2009). Recent developments in life cycle assessment. Journal of Environmental Management, 91(1), 1-21.

Forray, J. M., \& Leigh, J. S. (2012). A primer on the principles of responsible management education intellectual roots and waves of change. Journal of Management Education, 36(3), 295-309.

Foucault, M. (1970). The order of things: An archeology of the human sciences. Random House.

Fox, N. J., \& Alldred, P. (2016). Sociology and the new materialism: Theory, research, action. Sage.

Freeman, R. E. (1983). Strategic management: A stakeholder approach. Cambridge University Press.

Gad, C., \& Jensen, C. B. (2014). The promises of practice. The Sociological Review, 62(4), 698-718.

Garfinkel, H. (1967). Studies in ethnomethodology. Polity.

Garud, R., Gehman, J., \& Tharchen, T. (2018). Performativity as ongoing journeys: Implications for strategy, entrepreneurship, and innovation. Long Range Planning, 51(3), 500-509.

Gehman, J., Treviño, L. K., \& Garud, R. (2013). Values work: A process study of the emergence and performance of organizational values practices. Academy of Management Journal, 56(1), 84-112.

Gherardi, S. (2000). Practice-based theorizing on learning and knowing in organizations. Organization, 7(2), 211-223.

Gherardi, S. (2006). Organizational knowledge: The texture of workplace learning. Blackwell.

Gherardi, S. (2016). To start practice theorizing anew: The contribution of the concepts of agencement and formativeness. Organization, 23(5), 680-698.

Gherardi, S. (2019a). How to conduct a practice-based study: Problems and methods (2nd). Edward Elgar.

Gherardi, S. (2019b). If we practice posthumanist research, do we need 'gender' any longer? Gender, Work \& Organization, 26(1), $40-53$.

Gherardi, S. (2021). A posthumanist epistemology of practice. In M. Reihlen \& D. Schoeneborn (Eds.), Epistemology of management. Berlin: Springer.

Giddens, A. (1984). The constitution of society: Outline of the theory of structuration. Polity.

Grosser, K., \& Moon, J. (2019). CSR and feminist organization studies: Towards an integrated theorization for the analysis of gender issues. Journal of Business Ethics, 155(2), 321-342.

Hackley, C., Skalen, P., \& Stenfors, S. (2008). Marketing as practice. Scandinavian Journal of Management, 27, 189-195.

Hansen, E. G., \& Schaltegger, S. (2014). The sustainability balanced scorecard: A systematic review of architectures. Journal of Business Ethics, 133(1), 193-221.

Haraway, D. (1988). Situated knowledges: The science question in feminism and the privilege of partial perspective. Feminist Studies, 14(3), 575-599.

Haraway, D. J. (2016). Staying with the trouble: Making kin in the Chthulucene. Duke University Press.

Hibbert, P., \& Cunliffe, A. (2013). Responsible management: Engaging moral reflexive practice through threshold concepts. Journal of Business Ethics, 127(1), 177-188.

Hui, A., Schatzki, T., \& Shove, E. (Eds.). (2016). The nexus of practices: Connections, constellations, practitioners. Routledge.

Ibarra-Colado, E., Clegg, S., Rhodes, C., \& Kornberger, M. (2006). Ethics of managerial subjectivity. Journal of Business Ethics, 64(1), 45-55. 
Joyce, A., \& Paquin, R. L. (2016). The triple layered business model canvas: A tool to design more sustainable business models. Journal of Cleaner Production, 135, 1474-1486.

Karam, C. M., \& Jamali, D. (2013). Gendering CSR in the Arab Middle East: An institutional perspective. Business Ethics Quarterly, 23(1), 31-68.

Kellogg, K. C., Valentine, M. A., \& Christin, A. (2020). Algorithms at work: The new contested terrain of control. Academy of Management Annals, 14(1), 366-410.

Kennedy, S., \& Bocken, N. (2020). Innovating business models for sustainability: An essential practice for responsible managers. In O. Laasch, R. Suddaby, R. E. Freeman, \& D. Jamali (Eds.), The research handbook of responsible management (pp. 640-653). Edward Elgar.

Korica, M., Nicolini, D., \& Johnson, B. (2017). In search of 'managerial work': Past, present and future of an analytical category. International Journal of Management Reviews, 19(2), 151-174.

Laasch, O., \& Conaway, R. (2015). Principles of responsible management: Glocal sustainability, responsibility, and ethics. Cengage.

Laasch, O. (2018). Just old wine in new bottles? Conceptual shifts in the emerging field of responsible management. CRME Working Papers, 4(1), 1-13.

Laasch, O. (2021). Principles of management: Practicing ethics, responsibility, sustainability $(2 n d)$. SAGE.

Laasch, O., Moosmayer, D., Antonacopoulou, E., \& Schaltegger, S. (2020a). Constellations of transdisciplinary practices: A map and research agenda for the responsible management learning field. Journal of Business Ethics, 162, 735-757.

Laasch, O., Moosmayer, D., \& Arp, F. (2020b). Responsible practices in the wild: An actor-network perspective on mobile apps in learning as translation(s). Journal of Business Ethics, 161(2), 253-277.

Laasch, O., Suddaby, R., Freeman, R. E., \& Jamali, D. (2020c). Mapping the emerging field of responsible management: Domains, spheres, themes, and a future research agenda. In O. Laasch, R. Suddaby, R. E. Freeman, \& D. Jamali (Eds.), The research handbook of responsible management (pp. 2-38). Edward Elgar.

Lather, P., \& St. Pierre, E. A. (2013). Introduction: Post-qualitative research. International Journal of Qualitative Studies in Education, 26(6), 629-633.

Loacker, B., \& Muhr, S. L. (2009). How can I become a responsible subject? Towards a practice-based ethics of responsiveness. Journal of Business Ethics, 90(2), 265-277.

McCarthy, L. (2017). Empowering women through corporate social responsibility: A feminist Foucauldian critique. Business Ethics Quarterly, 27(4), 603-631.

McMurray, R., Pullen, A., \& Rhodes, C. (2011). Ethical subjectivity and politics in organizations: A case of health care tendering. Organization, 18(4), 541-561.

Miettinen, R., Samra-Fredericks, D., \& Yanow, D. (2009). Re-turn to practice: An introductory essay. Organization Studies, 30(12), 1309-1327.

Mitchell, R. K., Agle, B. R., \& Wood, D. J. (1997). Toward a theory of stakeholder identification and salience: Defining the principle of who and what really counts. Academy of Management Review, 22(4), 853-886.

Nicolini, D. (2012). Practice theory, work, and organization: An introduction. Oxford University Press.

Nicolini, D., Gherardi, S., \& Yanow, D. (2003). Knowing in organizations: A practice-based approach. Sharpe.

Orlikowski, W. J. (2000). Using technology and constituting structures: A practice lens for studying technology in organizations. Organization Science, 11(4), 404-428.
Ozkazanc-Pan, B. (2019). CSR as gendered neocoloniality in the global south. Journal of Business Ethics, 160(4), 851-864.

Padilla, E. (2002). Intergenerational equity and sustainability. Ecological Economics, 41(1), 69-83.

Painter, M., Pérezts, M., \& Deslandes, G. (2021). Understanding the human in stakeholder theory: A phenomenological approach to affect-based learning. Management Learning, 52(2), 203-223.

Painter-Morland, M. (2008). Business ethics as practice. Cambridge University Press.

Painter-Morland, M. (2011). Rethinking responsible agency in corporations. Journal of Business Ethics, 101(1), 83-95.

Pearce, D. (1988). Economics, equity and sustainable development. Futures, 20(6), 598-605.

Pérezts, M., Bouilloud, J.-P., \& Gaulejac, V. D. (2011). Serving two masters: The contradictory organization as an ethical challenge for managerial responsibility. Journal of Business Ethics, 101(1), 33-34.

Perezts, M., Faÿ, E., \& Picard, S. (2015). Ethics, embodied life and esprit de corps: An ethnographic study with anti-money laundering analysts. Organization, 22(2), 217-234.

Pickering, A. (1993). The mangle of practice: Agency and emergence in the sociology of science. American Journal of Sociology, 99(3), 559-589.

Prahalad, C. K. (2010). The responsible manager. Harvard Business Review, 88,36

Price, O. M., Gherardi, S., \& Manidis, M. (2020). Enacting responsible management: A practice-based perspective. In O. Laasch, R. Suddaby, R. E. Freeman, \& D. Jamali (Eds.), The research handbook of responsible management. Edward Elgar.

Puig de la Bellacasa, M. (2011). Matters of care in technoscience: Assembling neglected things. Social Studies of Science, 41(1), $85-106$.

Pullen, A., \& Rhodes, C. (2013). Corporeal ethics and the politics of resistance in organizations. Organization, 21, 782-796.

Raelin, J. A. (2020). Toward a methodology for studying leadershipas-practice. Leadership, 16(4), 480-508.

Rasche, A., \& Gilbert, D. U. (2015). Decoupling responsible management education: Why business schools may not walk their talk. Journal of Management Inquiry, 24(3), 239-252.

Reckwitz, A. (2002). Toward a theory of social practices: A development in culturalist theorizing. European Journal of Social Theory, 5(2), 243-263.

Rhodes, C., \& Pullen, A. (2018). Critical business ethics: From corporate self-interest to the glorification of the sovereign pater. International Journal of Management Reviews, 20(2), 483-499.

Rouse, J. (2001). Two concepts of practices. In T. R. Schatzki, K. K. Knorr Cetina, \& E. von Savigny (Eds.), The practice turn in contemporary theory (pp. 198-208). Routledg.

Sandberg, J., \& Tsoukas, H. (2015). Practice theory: What it is, its philosophical base, and what it offers organization studies. In R. Mir, H. Willmott, \& M. Greenwood (Eds.), The Routledge companion to philosophy in organization studies (pp. 184-198). Routledge.

Schaltegger, S., Burritt, R., \& Petersen, H. (2003). An introduction to corporate environmental management: Striving for sustainability. Greenleaf.

Schatzki, T. R. (2005). Peripheral vision: The sites of organizations. Organization Studies, 26(3), 465-484.

Schatzki, T. R. (2019). Social change in a material world: How activity and material processes dynamize practices. Routledge.

Schatzki, T. R., Knorr Cetina, K., \& Von Savigny, E. (Eds.). (2001). The practice turn in contemporary theory. Routledge.

Schneider, S. C., Zollo, M., \& Manocha, R. (2010). Developing socially responsible behaviour in managers. Journal of Corporate Citizenship, 39, 21-40. 
Schwartz, M. S., \& Carroll, A. B. (2008). Integrating and unifying competing and complementary frameworks: The search for a common core in the business and society field. Business \& Society, 47(2), 148-186.

Shen, J., \& Benson, J. (2016). When CSR is a social norm: How socially responsible human resource management affects employee work behavior. Journal of Management, 42(6), 1723-1746.

Shove, E., Pantzar, M., \& Watson, M. (2012). The dynamics of social practice: Everyday life and how it changes. Sage.

Taguchi, H. L., \& St. Pierre, E. A. (2017). Using concept as method in educational and social science inquiry. Qualitative Inquiry, 23(9), 643-648.

Thompson, N. A., \& Byrne, O. (2020). Advancing entrepreneurship as practice: Previous developments and future possibilities. In W. B. Gartner \& B. T. Teague (Eds.), Research handbook on entrepreneurial behavior, practice and process (pp. 30-55). Elgar.

Turner, S. (1994). The social theory of practices: Tradition, knowledge and presuppositions. Polity.

Ulmer, J. B. (2017). Posthumanism as research methodology: Inquiry in the Anthropocene. International Journal of Qualitative Studies in Education, 30(9), 832-848.

Vaara, E., \& Whittington, R. (2012). Strategy-as-practice: Taking social practices seriously. Academy of Management Annals, 6(1), 285-336.

Van Marrewijk, M., Wuisman, I., De Cleyn, W., Timmers, J., Panapanaan, V., \& Linnanen, L. (2004). A phase-wise development approach to business excellence: Towards an innovative, stakeholder-oriented assessment tool for organizational excellence and CSR. Journal of Business Ethics, 55(2), 83-98.
Verkerk, M. J., Leede, J., \& Nijhof, A. H. (2001). From responsible management to responsible organizations: The democratic principle for managing organizational ethics. Business and Society Review, 4(106), 353-379.

Waddock, S. (2004). Parallel universes: Companies, academics, and the progress of corporate citizenship. Business and Society Review, 109(1), 5-42.

Waddock, S., \& Bodwell, C. (2004). Managing responsibility: What can be learned from the quality movement? California Management Review, 47(1), 25-37.

Wesselink, R., \& Osagie, E. (2020). Differentiating CSR managers' roles and competencies: Taking conflicts as a starting point. In O. Laasch, R. Suddaby, R. E. Freeman, \& D. Jamali (Eds.), The research handbook of responsible management. Edward Elgar.

Wood, D. J., \& Logsdon, J. M. (2019). Social issues in management as a distinct field: Corporate social responsibility and performance. Business \& Society, 58(7), 1334-1357.

Wray-Bliss, E. (2009). Ethics: Critique, ambivalence, and infinite responsibilities (unmet). In M. Alvesson, T. Bridgman, \& H. Willmott (Eds.), The oxford handbook of critical management studies (pp. 267-285). Oxford University Press.

Publisher's Note Springer Nature remains neutral with regard to jurisdictional claims in published maps and institutional affiliations. 